\author{
Textbook: Focus on Students' National Identity
}

\title{
Promoting national identity: the case of language university students in Russia
}

\author{
Uliana V. Smirnova* (a)
}

(a) Moscow City University, 129226, Moscow (Russia), 4-1, $2^{\text {nd }}$ Selskokhoziastvenny Proezd

SmirnovaUV@mgpu.ru

\begin{abstract}
The contemporary context for facilitating cultural identification in Russian higher education is problematic with the main challenges for an educator encompassing the understanding of contemporary Russian identity and the methodological content and guidelines to promote it. The study investigates the national identity of Russian university students that they reveal in the course of studies at the Institute of Foreign Languages Moscow City University while doing adapted activities in a foreign coursebook. I argue that while students predominantly identify themselves as Russian their national identity reveals the complexity of intercultural and transcultural elements. The article proposes the understanding and knowledge students could be expected to learn in the process of promoting national identity (an understanding of what national identity and national identification mean and how the complexity of today's globalized world influence them; an understanding of what constitutes their "Russianness" and what could be elements of other cultures; an understanding of the role that the Russian language and culture play in their multilanguage identity; an understanding that they can be unconscious of how deeply they are influenced by home culture and that there might be contradictions between what they say and how they behave) and gives examples of activities in a foreign textbook adapted to promote Russian identification from the intercultural and transcultural approaches perspective. The research indicates that at the moment students do not feel that English class is the space where they can reveal their Russian identity.

Keywords: national identity, ELT, intercultural approach, transcultural approach.
\end{abstract}

\section{(C) 2021 Uliana V. Smirnova}

This is an open access article distributed under the terms of the Creative Commons Attribution License (CC BY 4.0), which permits unrestricted use, distribution, and reproduction in any medium, provided the original author and source are credited.

Published by Moscow City University and peer-reviewed under responsibility of TSNI-2021 (Textbook: Focus on Students' National Identity)

\section{Introduction}

\footnotetext{
* Corresponding author. E-mail: SmirnovaUV@mgpu.ru
} 
The pedagogical and political aspects of fostering a national identity have always been interconnected. Government bodies worldwide have been setting new priorities for the education of national values, including a necessity "to prevent children and young people from being drawn into terrorism" (DFE-00174, 2015). Under the Federal State Educational Standards in Russia, bachelors in Pedagogy are expected to be able to regard intercultural diversity of society from the social, historic, ethical, and philosophical perspectives. They are also to be able to guide their future pupils spiritually and morally with regards to fundamental national values (Federal State Educational Standards of Higher Education for the specialty "Pedagogical education", 2015). The targets set for university education by the Federal Standards indicate an intercultural methodological approach to promoting Russian cultural identification and refer to the content of this process, that is the knowledge of fundamental national values. However, some key questions remain unanswered and signal the complexity of the overall process:

1. What are the fundamental national values? How can "Russianness" be "contentualized"?

Globalization has influenced Russia like any other culture in the world. More importantly, serious social and political transformations have taken place in Russia and resulted in shifts in national identification. Drawing on the visions for Russian identity, which have been recently formulated in research (Trenin, 2019; Gadzhiev, 2019; Kofner, 2017; Skvortsov, 2017; Likhacheva et al., 2014), the social and educational policies should prioritize teaching an understanding that Russia has its own message to the world. Today the message is not based on a messianic set of ideas but seeks to promote Russia's state sovereignty and its role as "a major global player that refuses to take orders from anyone" (Trenin, 2019). The contemporary Russian values include education (as a projection to the future of Russia), the sense of ownership of one's country (as a reference to present), and a respectable acceptance of one's own history (as a connection to past) (Likhacheva et al., 2014, p. 11). Traditional Russian values refer to compassion, openness to other cultures and religions, freedom-loving, willpower, and talent (Skvortsov, 2017).

It is worth noting that teaching national values demands a national narrative. However, the choice of a narrative could potentially influence the perception of other national narratives and imply that they are "incorrect or inferior" thus "creating a historical journey of us and them" (Mansfield, 2019, p. 46; please see also Struthers, 2017; Vincent, 2019). This aspect inevitably raises the issue of an approach in the education of national identity.

2. Which is the best approach to fostering a sense of national identity? 
National identity is one of the focuses of the intercultural approach in ELT. The intercultural approach is meant to prepare learners for global interaction by ensuring an intercultural space for cultural dialogue. The constructed intercultural ground encompasses the knowledge of other cultures, the awareness of the fact that there are differences between various cultures, and, among all, a clear sense of national identity as learners are meant to develop an understanding of their own culture from two opposite directions: from inside, by learning their national cultural standing and from outside, by getting an opportunity to see a home culture through the lens of other cultures.

There has recently appeared another approach that might be productive in the education of national identity. The most advantage of this approach is in the way "culture" and "cultural identity" are mediated in the course of teaching and learning. According to most culture-based approaches, culture is implicitly a homogeneous totality. It manifests itself in the form of local varieties and comes in contact with other similarly homogeneous cultures and languages in the global domain. The transcultural approach critiques and warns against this view on culture and reflects on the culture as an open construct that is characterized by intertwinement and pluralization of identities (de Souza, 2017, p.8-12). Such understanding results in new pedagogical practices that allow learners to become aware of the plurality of their identity and reveal it in class.

3. Are the differences between national identities disappearing?

In the globalized cultural context, the very notions "nation" and "citizen" have been thoroughly reconsidered. Globalization has been leading to the global integration of economies, societies and cultures and has resulted in a great level of unification. In the classroom, this phenomenon could be attested to and recognized as the formation of a global hybrid identity (Rapoport, 2020). The digitalization of sociality through deterritorialized spaces of communication has also been contributing to the rise of global identities (Liogier, 2020). Given these changes education research has been concentrated on fostering a sense of national identity, on the ground that it is conducive to national unity (LUO, 2019), especially in the very complex political and economical environment of today. It is worth noting that transcultural and hybrid are contrarily different philosophical notions with hybridity resulting in a loss of national identity and transculturality meaning gaining awareness of the richness and complexity of your identity.

In a nutshell, the research area of concern involves the quickly changing realities of national identity formation, some new political and pedagogical facets of Russian national identity, and the choice of approaches to fostering a sense of national identity. 


\section{Purpose and objectives of the study}

I aim to explore potential pedagogical decisions a teacher can take to promote national identity in English class. More specifically, the research is concerned with the ways activities in a foreign textbook could be adapted or extended to serve this purpose. I analyze the complexity of the national identity of Russian students and uncover the potential of a transcultural approach in this process.

\section{Literature review}

From the discursive point of view, the formation of personal identity is a constant positioning between I (the speaker) and the Other (Zheltukhina et al., 2016). As a result, identification never ends as identity undergoes continuous "negotiation, reshaping, transformation, while people engage in daily ordinary communication with others" (Yus, 200, p. 3730).

National identity is two-fold: it is a matter of both "being" and "becoming" (Hall, 1993). This understanding is reflected in educational research as the division between a process and a result (Gornostaeva, 2017; Murasova, 2009). The process indicates methodological content and guidelines used to promote "becoming" a national citizen, and the result is the evaluation of how much national culture is shared and held in common with people of the same history and ancestry. In this regard, experts outline three levels of national identity formation: attributive, emotive and inculturational (Gornostaeva, 2017), surface, middle-deep and in-depth (Shuklinova, 2005), or basic, middle and highest (Skvortsov, 2017).

At the surface level, a person positions himself or herself as belonging to a nation through geographical identification or due to the fact of birth on this particular territory. At the middle-deep level of national identification, a person expresses positive emotions towards the fact of belonging to a particular nation and can dwell on cultural ideals and examples that cause this sense of positivity or pride in their own country. At the in-depth level, a person can explain why they feel belonging to a particular nation with regards to the system of cultural values and patterns of behaviour. The examination of national identity incorporates a selection of knowledge that a person reveals about a nation: an understanding and knowledge of national literature, cinematography, art refer to the surface level, the middle-deep level realizes itself in the knowledge of national traditions and customs, and the in-depth level results from the knowledge of the role your nation and country has played in the world history and culture (Shuklinova, 2005, p. 7). Such key elements as rites, rituals, myths, legends, stories, symbols, language, physical setting, and artifacts are used in matching an individual national identity to the collective exemplified model (Flak, 2019). Challenged with a necessity to cultivate a national identity an educator decides on the choice of avoidance, promotion, rejection and problematisation (Sant \& Hanley, 2019). 
Traditionally, the education of national identity centers mostly around the role of social-cultural examples or ideals with which learners learn to identify in the course of studies. They give clues to cultural norms, patterns of behaviour, and values that mediate people's understanding of their national identity (Mazurenko, 2009, p. 11-12). Mental processes underlying cultural identification often operate at a largely automatic or non-conscious level (Devos \& Vu, 2014). From this point of view, unconscious knowledge, beliefs and attitudes could be surfaced and promoted in the education process through specially designed activities (Zinchenko, 2019) or they could be used in the construction of neotraditional recreations or simulations (Yakovlev et al., 2019).

It is vital to note that identification is a signifying process, "once secured, it does not obliterate difference" and "obeys the logic of more than one" (Hall, 1996, p. 3). S. Hall, whose fundamental work I quote, never mentions a transcultural approach; however, his words signal the necessity of a transcultural approach that sees identity as a complex multicultural entity with non-essentialist properties. From this position, the transcultural approach is not limited to teaching English as an international language (Yazykova et al., 2020) but presents itself as a pedagogical stance that deals with shifted views on identity and acknowledges that national identity could be plural and multilingual.

The cornerstone of the research on cultivating national identity in the process of learning and teaching foreign languages is the nature of ELT materials and the overall concern about the lack of local cultural realities in a lesson. While opening access to English language education, ELT materials pose a risk of culture alienation (e.g. Yang \& Lu, 2016). Even when culture-based activities are added or adapted, the local culture component is reduced to national geography and stereotypes, which might not work to facilitate national identity while learning (Toledo-Sandoval, 2020).

There is a separate direction of research aimed to promote national identity in multi-ethnic societies with a strong sense of regional and local identities. In multi-ethnic countries like Russia or China with great regional cultural variety, the context of national identity education differs from the countries like the USA, where the duality of Americanism ("monocultural versus multicultural") results from immigration (Yang, 2020). Integration of local and regional identities to national identity is an urgent issue, as, according to some research (Habib, 2018), pupils see themselves as belonging to a particular local area before a nation. With regards to Russia, K. Gadzhiev $(2019$, p. 114, 115) believes that the formation of national identity in multi-ethnic Russia should target "a sense of socio-cultural, political-cultural consolidation of Russian cocitizenship" and the shared "national mission".

\section{Methodology}


The results given in the article describe the research taking place within one semester of English as a foreign language for undergraduates in pedagogy at the Institute of Foreign languages, Moscow City University. The participants were in their fourth year of studies. The participants were native speakers of Russian and learners of French or Italian and English. They had English classes once a week, the whole duration of classes was 3 hours, there were two 1.5 hour classes. The learners' level of English was B2- C1. There were 11 students in the "Italian" group (the group in which the first foreign language was Italian) and there were 15 students in the "French" group (the group in which the first foreign language was French). The atmosphere in the groups was quite friendly as the learners had got to know each other well by their 4th year of studies.

Data was gathered at six points, from October 2020 to December 2020 in the form of students' reflective essays and discussions; for reasons of space, the results from only two points are given in the article. The research is qualitative. The lessons did not explicitly address the domain of national identity, however, I adapted activities in the coursebook to address students' national identity while covering different curricular content (e.g. globalization, emotions, the uses and contexts of language). I relied on the transcultural approach to teaching foreign languages and problematisation strategy, which means that the students were regularly asked to critically examine their sense of national identity by the following procedure:

1. A teacher explores an activity in the coursebook from the national identity perspective. It means asking questions that are related to students' opinions and experience concerning the three levels of national identity: surface (knowledge of cultural realities and phenomena), middle (knowledge of patterns of behavior and attitudes), in-depth (knowledge of a nation's standing in the world from the axiological and historical angle).

2. Before or during an activity a teacher discusses the key terms and promotes an understanding of what "identity", "nation", "nationality", "culture", "globalization", "transculturality", "transcultural", "translanguaging" mean. In the course of studies Teacher regularly returns to these definitions and encourages understanding of their non-essentialist properties.

3. On the assumption that there will be contradicting answers due to the mixture of conscious and unconscious layers of cultural identity, a teacher problematises or challenges students' answers.

5. A teacher asks students to do reflexive writing at the end of a lesson as a short writing activity or homework. The main questions embrace possible contradictions or disproportions in students' answers, their attitude to the problem discussed in class, potential changes in opinions, insights into their identity. 
The research gives only preliminary results and concentrates on adopted activities in a foreign coursebook. The curriculum textbook used in the research was the Cutting Edge Advanced Student Book and Workbook, new edition, by S. Cunningham, P. Moor, J. Bygrave, D. Williams (2014).

\section{Results}

The results of the research encompass my vision for the understanding and knowledge students are expected to learn in the process of promoting national identity, the examples of activities adopted from the coursebook, and the patterns in the students' answers that reveal specific features of their national identity.

The understanding and knowledge students are expected to learn include:

an understanding of what national identity and national identification mean and how the complexity of today's globalized world influence them;

an understanding of what constitutes "Russianness" in their national identity and what could be elements of other cultures;

an understanding of the role that the Russian language and culture play in their multilanguage identity;

an understanding that they can be unconscious of how deeply they are influenced by home culture and that there might be contradictions between what they say and how they behave.

The paper gives examples of two activities adopted from the Cutting Edge Advanced coursebook and aimed to promote national identity in English class.

Activity 1. Reading about emotions across cultures (Cutting Edge Advanced Student book. Module 2. Emotions. pp. 18 -19. Text by Melissa Thompson "Expressing emotions across cultures").

Original task for the after-reading activity. Work in groups and discuss one or more of the questions: Do you generally express your emotions or do you tend to bottle up your feelings? Is it acceptable in your country to express negative emotions like anger? Do you think it is good to express negative emotions? In what circumstances? Have you ever experienced a culture where emotions are expressed differently from your own? What differences did you notice?

Adapted (extended) task. Take part in the discussion: What is an individualistic culture? What is a collective culture? Is Russian culture individualistic or collective? Do you feel free to express your anger or grief in public? 
Methodological guidelines. All questions are designed to promote cultural awareness, however, I think it is necessary to clarify students' understanding of what individualistic and collective cultures mean and refer them to the description of the difference between cultures in the text. It is important to ask students if they think Russian culture is individualistic or collective. In my experience, students unanimously said that Russian culture used to be collective in the Soviet Union and it is individualistic at the moment. However, their answers contradicted the answers to another question about feeling free to express emotions in public. The overwhelming majority said that they never or very rarely express their emotions in public because they do not feel it is appropriate. This pattern of behavior signals a collective culture. A teacher can problematise by asking students how they could explain the contradiction between their opinion of Russian culture as individualistic and their unease to express emotions in public which indicates a collective culture?

National identity through the lens of students' answers. Students reveal their knowledge of the USSR and understanding that the USSR was a collective culture in which their parents and grandparents were raised and still belong to. Although students believe they live in a different country now, they acknowledge that the USSR's past has influenced them.

Students express a belief that nowadays Russian culture is individualistic because people have become more concentrated on their life goals, have learned to prioritize individuality, not the state. In general, students express a positive attitude both to the past because it is connected with their family and to the present. Negative opinions are viewed about the way people express their emotions in Russia. "When I was in Italy everybody was smiley and polite. As soon as I crossed the border everything went gloomy and pessimistic. I do not like it. Maybe it is because life is difficult in Russia or we feel constrained about expressing positive emotions" (from a student's answer). Students feel that expressing emotions in public is not taboo in Russia, yet considered inappropriate.

Activity 2. Describing a story you like from a film, book or play. Choose a story that provokes strong emotions (Cutting Edge Advanced Student Book, Module 2. Emotions, pp. 22-23).

Original task. Work alone or in pairs; Choose a story you like from a film, book or play to describe to the class; Check details of the story online if necessary.

Adapted (extended) task. Write a story you like from a film, book or play at home, practice telling the story till you feel confident to describe it to the class; Present the story to the class; Listen to the other students' stories and choose the one you like the most; Take part in the discussion generated by the teacher; Do some reflexive writing on the question provided by the teacher. 
Methodological guidelines to the discussion generated by the teacher. In my experience, students do not choose Russian stories, so at the end of the activity a teacher can ask students how they can explain the fact that none (very few) of them have chosen a story from a Russian book, film or play. A teacher can ask to do a piece of reflexive writing to answer the questions "Why did you choose this or that book, play and film"; "What does your choice reveal about your identity (national identity)?", "Why did not you choose a Russian book, play or film?".

National identity through the lens of students' answers. When students' sense of national identity was problematised, they revealed the knowledge of classic Russian books and authors studied at school (Anna Karenina by Leo Tolstoy, Dostoevsky, Checkov), famous Soviet and Russian film directors A. Tarkovsky, A. Zvyagintsev, K. Serebrennikov, S. Dvortsevoy, modern Russian writers D. Bykov, S. Minaev, L. Ulitskaya, the biographical Russian series "The Dyatlov Pass". However, the results prove that the students' national identity is immensely influenced by foreign books and films. From the axiological perspective, the students regularly emphasize intercultural values like a "dialogue of cultures" and "respect to other cultures", which, I believe, they have internalized and adopted in the course of university studies.

A qualitative analysis of answers reveals some clear patterns in the students' understanding of their identity. Only the most illustrative answers are given.

English class is not the place to reveal Russian identity:

"It was an assignment on the subject of a foreign language, and perhaps there was a rule that unconsciously worked in our heads - if it is English, then the film or the book must be foreign".

"Honestly, I am convinced that the overwhelming majority of our group chose different foreign films and books, in particular, English and American pieces of art, not because they don't like or even know Russian ones, but because they found it rational to choose something from foreign countries for a lesson of a foreign language"

"I'd like to emphasize the fact that all of us are students at the institute of foreign languages that's why we wish to be closer to the cultures of the target languages".

Feeling global:

"I have studied different cultures since childhood, so I have never considered myself one of them. After living in Europe, when I was on an internship in Italy for a long time, I generally stopped feeling the national line, so the choice of my favorite film doesn't depend on the place of its creation, but only on the 
quality of the film".

"Russian films or series often emphasize Russian identity, which loses its relevance for students who are studying foreign languages and their cultures. Also, as students of the Faculty of Foreign Languages, we are taught to read between the lines and look into the essence of the culture of the works that we touch. I can't say my identity is Russian, I feel like I'm "a person of the world".

Feeling transcultural:

"When in America I discovered one important thing about myself. I'm an ordinary person who was raised on mom's authentically Slavic fairytales. However, I discovered that I wasn't any different from the American people that I had previously thought. I didn't feel like a stranger. First of all, my food preferences didn't change while I was living in America. I eat eggs, bread, avocado, salmon, porridge, sandwiches for breakfast, burgers, mash potatoes, pasta, meat, chicken for lunch or dinner. Probably it is because our food preferences in Russia are a little bit Americanized, Secondly, I could speak with Americans about their culture as I knew quite a few things about it. I suddenly understood that I know a lot of American classical writers, I have watched a lot of films and I'm listening to American music nonstop. Maybe our generation is too Americanized, maybe my studying at the Language University has made me think the way people of the aim-language do. Moreover, my clothes were also similar. I'd like to say that visiting other countries enriches everyone, but it can also help discover you have more identity than one".

"All in all, despite our preferences, I don't think that we stop identifying ourselves like Russian. We take a lot of cultural qualities from foreign books and films, but it happens all over the world because of the globalization process".

Feeling intercultural:

"It didn't take long to decide between Les Miserables and Anna Karenina, which I reread a couple of years ago. Both are fundamental works of literature. And my choice of a foreign book is influenced by my broad outlook and interest in many things that are happening in the world. It is important to know and understand our nation, but at the same time we must respect other cultures".

Feeling that foreign culture has more to offer to the young adults:

"I think the reason why no one in our class chose a Russian movie is that Russian cinematography, unfortunately, cannot provide anything that could appeal to young people. The Russian film industry has literally nothing to offer that could be catchy and interesting for them. As for the old films, I think that 
none of us watches such works anymore, because they are mostly about the times of the USSR, and young people are more focused on the future, on changes. Foreign films are made more efficiently and have an interesting plot in comparison with the Russian ones".

"Russian films are banal and one-dimensional in nature".

\section{Discussions}

Upon reflection, there are always contradictions between what students say and how they behave. Their behaviour reveals deep levels of Russianness that do not perceive or, rather, are not taught to analyse and reflect upon. They feel that a lesson of English is not the place where they can reveal their Russian identity. It happens because of the lack of national identity focus in class due to the nature of foreign coursebooks. The second factor that contributes to students opting out is that they lack the knowledge and practice to introduce Russian culture into activities as it demands analytical guidelines from the teacher.

A great extent of interculturality and transculturality is revealed in class. I believe intercultural elements happen to surface because of the education students have been receiving at the Institute of Foreign Languages with its strong emphasis on intercultural competence. The students use in their writings such terms from the theory of intercultural communication as "second language personality", "mutual respect", "cultural parity" and are skilled to compare cultures to identify the spaces of differences and similarities. Academic mobility of students also enriches the students' experience in cross-cultural communication. Transculturality surfaces mostly in terms of shared clothes, food and music preferences. Despite the seeming superficiality of such transcultural indexes, I believe transculturality goes deeper to reach the level of students' views and attitudes, however, it needs more time to research this aspect

Foreign culture seems more appealing to students as they feel heavily attracted to the ideas and images of foreign culture that appear more actualized in their contemporary cultural context. This view is also projected into a foreign language class, which is limited to foreign cultural realities.

\section{Conclusion}

The research conducted has given some preliminary results that indicate how complicated for the teacher the process of fostering a national identity is. In essence, the education of national identity has three main dimensions: political, pedagogical and philosophical. The political agenda is set by the necessity to engage with the young to keep the Russian Federation consolidated, while the pedagogical dimension is concerned with the content and activities that could strengthen a sense of national identity. The philosophical 
dimension, which is equally important, deals with the views on identity, nation, nationalism and nationality that fundamentally define the choice of an approach. Along with an intercultural approach, a transcultural approach might also be of great use. It can reveal how complex and fluid our identities have become in today's globalizing world. More importantly, the transcultural approach could potentially eliminate a risk of othering and marginalisation which could arise from differentiating cultures and could help to balance the promotion of national identity with problematisation that takes into account the multifacetedness of young adults' national identity and its unconscious nature.

The preliminary results show that students' national identity has some transcultural elements (which means that cultures co-exist and merge within an individual), intercultural (which point to cultures differentiated, yet acknowledged to be on par) and global (when an individual identifies as having no national identity). Though foreign textbooks do not have any special culture sections or texts dedicated to Russian culture, their activities could be effectively adapted or extended to serve the goal of promoting Russian cultural identification. The understanding and knowledge university students are expected to learn encompass the changing realities of communication and the complex nature of a national identity that might be identified as a fluidity of cultures.

The analysis of students' reflective essays proves useful in the future directions of research on the methodology of fostering a sense of national identity in English class. The most striking result, in my opinion, is the fact that students exclude their Russian identity from an English class. Efforts should be taken to reveal the complexity and multiplicity of their identities through materials and activities to change this view. At this phase of research, it appears that students are guided by their family upbringing (in the form of fairytales, Russian books, films, views shared in the family), secondary school education (mostly the knowledge of classic writers and historic events), the circle of friends (doing some culture together like meeting once a week and watching films), the language university education (the intercultural competence).

The size and the contextualized nature of the research do not allow me to claim the statistical representativeness of the students' views. However, I believe it provides many clues for future directions of study.

\section{References}

de Souza, L. M. T. M. (2017). Multiliteracies and Transcultural Education. In O. Garcia, N. Flores, M. Spotti (Eds.) The Oxford handbook of Language and Society (pp. 262-280). Oxford: Oxford University Press. http://doi.org/10.1093/oxfordhb/9780190212896.013.20 
Devos T., \& Vu T. L. (2014). Implicit Multicultural Identities. In V. Benet-Martinez, Y-Y. Hong (Eds). The Oxford handbook of multicultural identity. (pp. 227-251). Oxford: Oxford University Press. http://doi.org/10.1093/oxfordhb/9780199796694.013.004

DFE-00174-2015 (2015, August 17). Protecting children from radicalisation: the prevent duty. Retrieved from Department for Education. https://www.gov.uk/government/publications/protecting-childrenfrom-radicalisation-the-prevent-duty

Federal State Educational Standards of Higher Education for the specialty "Pedagogical education". (2018, February 22). Retrieved from the Ministry of Science and Education of Russia. http://fgosvo.ru/news/21/3576

Flak O. (2019). System of organizational terms as a theoretical foundation of cultural identity research using an online research tool for teaching reflective practice. International Journal of Art and Sciences, 12(01), 243-256.

Gadzhiev K. (2019). Kamaludin Gadzhiev reflections on the features of the national identity of Russia. Social Sciences, 8(3), 107-116. http://doi.org/10.11648/j.ss.20190803.16

Gornostaeva E.E. (2017). Kulturnoe samoopredelenie starsheklassnikov pri obuchenii socialnogumanitarnym disciplinam: avtoref. dis. ... kand. ped. n. 13.00.01 [Cultural identification of secondary school pupils during learning subjects from social science and humanitarian curriculum. Abstract of dissertation for the degree of candidate of pedagogy]. Volgograd: Volgograd State Socio-Pedagogical University.

Habib S. (2018). Learning and teaching British values: policies and perspectives on British identities. London: Palgrave Macmillan.

Hall S. (1990). Cultural identity and diaspora. In J. Rutherfold (Ed.) Identity: community, culture, difference. (pp. 222-237). London: Lawrence \& Wishart Ltd.

Hall S. (1996). Who needs identity? In S. Hall, P. du Gay (Eds.). Questions of cultural identity. (pp. 1-17). London: Sage Publications.

Kofner Yu. (2017, September 13). The national identity of Russia in the 21st century. Retrieved from https://russiancouncil.ru/en/blogs/GreaterEurasiaEnglish/the-national-identity-of-russia-in-the-21stcentury/ 
Likhacheva A., Makarov I., Andreev P., Gabuev A., \& Makarova E. (2014, April 14). Report: National identity and Russia's future. Retrieved from Valdai Discussion Club https://valdaiclub.com/a/reports/national_identity_and_russia_s_future/

Liogier R. (2020). Identités globales et religion à l'ère digitale: vers les Global Identity Studies. Social Compass, 67 (4), 553-575. http://doi.org/10.1177/0037768620953508

LUO Ch. (2019). Cultural identity and national unity education based on the perspective of intercultural interaction in college freshmen enrollment psychology. Revista de cercetare si interventie sociala, 66, 389-407.

Mansfield A. (2019). Confusion, Contradiction and Exclusion: The Promotion of British Values in the Teaching of History in Schools. Curriculum Journal, 30(1), 40-50. http://doi.org/10.1080/09585176.2018.1533483

Mazurenko N.V. (2009). Nacionalno-kulturnaja identichnost v uslovijah globalizacii: socialno-filosofskij analiz: avtoref. dis. ... kand. philos. n. 09.00.11 [National identity in the context of globalization: social and philosophical analysis. Abstract of dissertation for the degree of candidate of philosophy]. Moscow: Russian Presidential Academy of Public Administration.

Murasova A.R. (2009). Pedagogicheskoe soprovozhdenie kulturnogo samoopredelenija studentov [Pedagogical guidance in the process of students' cultural identification]. Ulyanovsk: Ulyanovsk State Technical University.

Rapoport A. (2020). Development of Global Identity in the Social Studies Classroom. Journal of Social Studies Education Research, 11 (1), 1-20.

Sant E., \& Hanley C. (2018). Political Assumptions Underlying Pedagogies of National Education: The Case of Student Teachers Teaching 'British Values' in England. British Educational Research Journal, 44 (2), 319-337. http://doi.org/10.1002/berj.3331

Skvortsov N. (2017). The Formation of National Identity in Contemporary Russia. Changing Societies \& Personalities, 1(1), 74-83. http://dx.doi.org/10.15826/csp.2017.1.1.005

Shuklinova M.V. (2005). Nacionalno-kulturnaja identichnost' studentov provincialnyh vuzov: avtoref. dis. ... kand. soc. n. 22.00.06 [The national identity of students at regional educational institutions. 


\begin{abstract}
Moscow: Moscow Humanitarian University.
\end{abstract}

Struthers A. E. C. (2017). Teaching British values in our schools: but why not human rights values? Social and Legal Studies, 26(1), 89-110. http://doi.org/10.1177/0964663916656752

Toledo-Sandoval F. (2020). Local culture and locally produced ELT textbooks: How do teachers bridge the gap? System, 95, 102362. http://doi.org/10.1016/j.system.2020.102362

Trenin D. (2019, July 18). Russia's changing identity: in search of a role in the 21 st century. Retrieved from https://carnegie.ru/commentary/79521

Vincent C. (2019). Cohesion, Citizenship and Coherence: Schools' Responses to the British Values Policy. British Journal of Sociology of Education, 40(1), 17-32. https://doi.org/10.1080/01425692.2018.1496011

Yakovlev A., Antonov I., \& Fedorov S. (2019). (Neo)traditionalism as a form of cultural identity of the inhabitants of Yakutsk. Advances in Social Science, Education and Humanities Research, 364, 809813. https://doi.org/10.2991/icsdcbr-19.2019.166

Yang M. (2020) The American dream: immigration and formation of cultural identity in the United States. Dialogos, 24(1), 178-201. http://dx.doi.org/10.4025.dialogos.v23i3.51952

Yang Y., Lu F. (2016). Cultivating college students' national cultural identity based on English education. English Language Teaching, 9(5), 192-196. https://doi.org/10.5539/elt.v9n5p192

Yazykova N. V., Goncharova V.A., \& Budnikova A. A. (2020). Transcultural approach to teaching English as an international language: goal setting. EpSBS, 95 (DCCD-2020), 1195-921. https://doi.org/10.15405/epsbs.2020.11.03.126

Yus F. (2015). Discourse and identity. In N. J. Smelser, P.B. Baltes (Eds.) International Encyclopedia of the Social \& Behavioral Sciences. (pp.3728-3732). Oxford: Pergamon.

Zheltukhina M.R., Vikulova L.G., Serebrennikova E.F., Gerasimova S.A., Borbotko L.A. (2016). Identity as an element of human and language universes: axiological aspect. International Journal of Environmental and Science Education, 11(17), 10413-10422. 
Zinchenko Yu. (2019). Ethnocultural Identity as Social Stability Factor: Development of a Systemic Model of Research and Forming of Positive Interethnic and Interreligious Attitudes from the Perspective of a Postnonclassical Paradigm (Using Virtual Reality Technology and Psychophysiological Diagnostics). (Report No. 18-18-16012). Retrieved from Russian Science Foundation website https://www.rscf.ru/enprjcard_int?18-18-16012Esteve-Mon, F. M., Cela-Ranilla, J. M., \& GisbertCervera, M. (2016). ETeach3D: Designing a 3D virtual environment for evaluating the digital competence of preservice teachers. Journal of Educational Computing Research, 54(6), 816-839. https://doi.org/10.1177/0735633116637191 